\title{
Opa! Did EU Entry Contribute to the Greek Crisis?
}

\author{
Alexi Thompson ${ }^{1}$, Koichi Yamaura ${ }^{2}$ \\ ${ }^{1}$ Department of Agricultural Economics, Kansas State University, Manhattan, USA \\ ${ }^{2}$ Graduate School of Global Environmental Studies, Sophia University, Tokyo, Japan \\ Email: alexit@ksu.edu
}

Received August 17, 2013; revised September 15, 2013; accepted September 23, 2013

Copyright (C) 2013 Alexi Thompson, Koichi Yamaura. This is an open access article distributed under the Creative Commons Attribution License, which permits unrestricted use, distribution, and reproduction in any medium, provided the original work is properly cited.

\begin{abstract}
This paper focuses on possible underlying causes of the current Greek debt. The Gregory and Hansen residual-based cointegration test is to test Greek deficit sustainability with annual data from 1988 to 2012 . This cointegration test identifies structural breaks when they are unknown a priori. Estimated results reveal a break in 1996 . The break in 1996 coincides with the election of Simitis as prime minister, suggesting that the current debt problem may be due to increased government expenditure associated with the tenure of Simitis rather than due to EU entry.
\end{abstract}

Keywords: Greek Crisis; Time Series; Gregory and Hansen Cointegration Test

\section{Introduction}

Despite the passage of harsh austerity measures by the Greek Parliament to obtain financial bailouts from the European Union (EU), the future of Greece is uncertain. Many European leaders and economists support a Greek bailout, worrying about a run on European banks. They also fear that larger economies such as Spain, Italy, Portugal, and Ireland may follow in Greece's footsteps and default. On the other hand, some economists and many rioting Greeks favor default and return to the drachma. These economists fear that the EU bailouts are only delaying the inevitable. Some favor a default, comparing Greece's economic situation to Argentina's crisis in 2001 [1]. Argentina was able to recover from their default quickly, in part due to their strong export market. Greece's export levels are currently much higher than Argentina's export levels in 2001.

Before assessing the different paths Greece may take, it is necessary to understand what got the country into this mess in the first place. Rampant tax evasion and corrupt inefficient government are largely to blame [2]. In 1996, Andreas Papandreou resigned as Greek prime minister leading to the election of Costas Simitis who undertook public projects such as the Athens metro, Venizelos International Airport, a northwestern, highway Egnatia Odos, and Rio-Antirio Bridge, in part for the 2004 Olympic Games. The cost of the Olympic Games including improvements in infrastructure was $\$ 15$ billion, approximately $7.8 \%$ of GDP in 2003 , although the esti- mated cost was $\$ 5.9$ billion [3]. In 2004, Greek Prime Minister Karamanlis faced a financial audit. The government-debt crisis began in 2010 under Prime Minister Pandreou's term.

Besides these increases in government spending, recent papers have discussed the possibility of EU entry contributing to the failure of the Greek bond market [4]. Before EU entry, investors knew that Greek bonds were risky. After EU entry, investors perhaps were misled into believing that Greece, in case of financial difficulty, would be bailed out by EU member countries. Thus, Greek bonds became overvalued. Germany's reluctance to financially support Greece in 2008 may have only worsened the crisis as investors tried to simultaneously unload their Greek bonds.

This paper attempts to address whether the cause of the current Greek crisis rests solely on the shoulders of the Greek government, or if EU entry contributed to the crisis. In the following, [5] we use the Gregory and Hansen residual-based cointegration test [6] to test for sustainability of the Greek fiscal deficit. This cointegration test allows for breaks in the data, extending the Engle Granger test [7]. Assuming the Greek deficit is not sustainable, a break in 2001 would be evidence that the current crisis is in part due to EU entry.

\section{Theory}

The government's one period budget constraint assuming one year maturity takes the form; 


$$
G_{t}+\left(1+i_{t}\right) B_{t-1}=T_{t}+B_{t},
$$

where $G_{t}$ is government purchases, $T_{t}$ is government revenue, $B_{t}$ is government debt, and $i_{t}$ is annual interest rate. Solving for the government's intertemporal budget constraint and assuming no Ponzi scheme, government debt must equal budget surplus [5]. [8] take this theory and show the following regression model for analyzing the sustainability of Greek government debt;

$$
T_{t}=a+b G G_{t}+e_{t},
$$

where $G G_{t}$ is government spending inclusive of interest payments on debt and $b$ is the coefficient on government spending. If $T_{t}$ and $G G_{t}$ are not cointegrated, then government debt is unsustainable. If $T_{t}$ and $G G_{t}$ are cointegrated then government debt is sustainable. When $T_{t}$ and $G G_{t}$ are cointegrated with estimated coefficient $b<1$ government debt is unsustainable.

\section{Estimation and Results}

Annual Greek government spending and revenue data span from 1988 to 2012 and come from [9]. Figure 1 shows annual Greek government spending and revenue data from 1988 to 2012. Greece was in debt over the entire time period (see Figure 2), and has rapidly increased since 2002. It should be noted that in years preceding EU entry the deficit gap shrank substantially as Greece attempted to meet EU entry requirements. Once Greece entered the EU, however, the deficit gap began to increase slowly before rapidly increasing in 2008 .

Following [5], the Gregory and Hansen residual-based cointegration test (GH test) is used to further investigate Greek debt sustainability over this time period. This cointegration test has the advantage over other cointegration tests in that it tests for significant breaks in the data when they may not be known a priori. The GH test reports three test statistics; ADF, $Z_{t}$, and $Z_{\alpha}$, and rejection of the null hypothesis indicates a significant break for each test.

Before cointegration tests, we test for stationarity. Table 1 shows Dickey-Fuller unit root tests and the results indicate the first differences of the series are stationary.

Now we test for cointegration between $\operatorname{Rev}_{t}$ and $\operatorname{Exp}_{t}$ by Engle-Granger's residual-based test that assumes no structural break. Table 2 shows Engle-Granger cointegration test. The results show that we cannot reject the null of no cointegration. This indicates that Greek government fiscal deficits are not sustainable.

Next, we test for cointegration with unknown structural breaks using Gregory and Hansen cointegration test. As in [5], we consider the level shift model of Gregory and Hansen that takes the form;

$$
y_{t}=\mu_{1}+\mu_{2} \varphi_{t}+\alpha x_{t}+u_{t}, t=1, \cdots, n,
$$

where $\varphi_{t}$ is a year dummy based on the breaks found

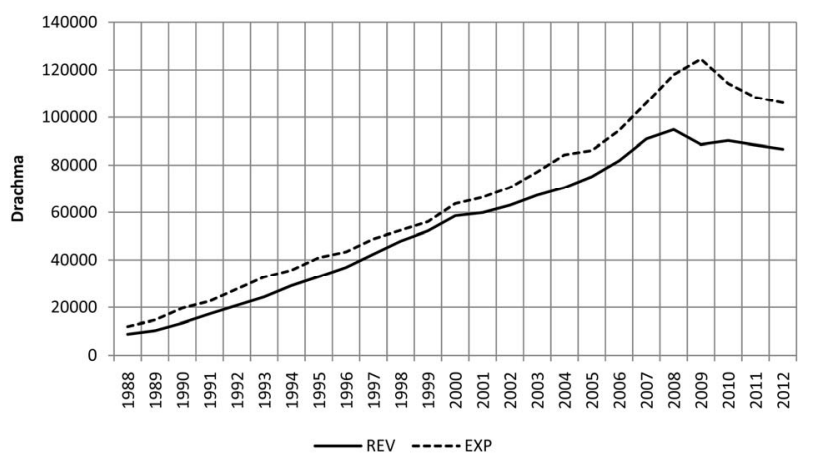

Figure 1. Annual greek government spending and revenue data from 1988 to 2012.

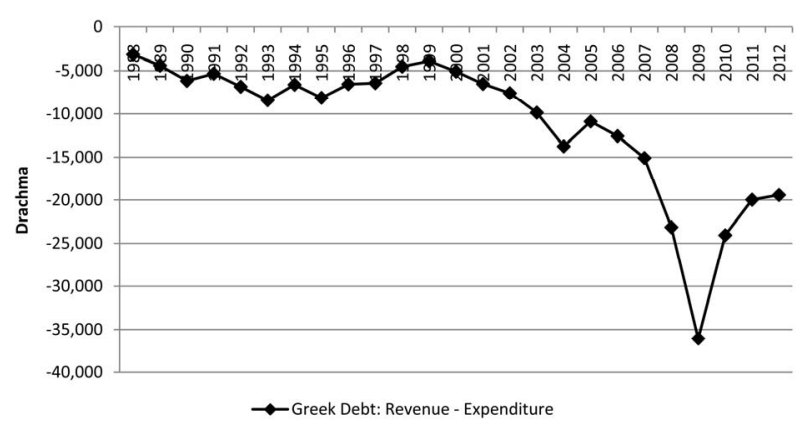

Figure 2. Annual greek government debt from 1988 to 2012.

Table 1. Augmented dickey-fuller unit root tests.

\begin{tabular}{cc}
\hline & Test Statistic \\
\hline $\operatorname{Rev}$ & $-8.307^{* * *}$ \\
$\exp$ & $-6.234^{* * *}$ \\
\hline
\end{tabular}

${ }^{* * *}$ is statistically significance at the $1 \%$ level.

Table 2. Engle-Granger cointegration test.

\begin{tabular}{cc}
\hline & Test Statistic \\
\hline Engel-Granger & -1.784 \\
\hline
\end{tabular}

The $5 \%$ critical value is -3.00 and is determined using McKinnon's (1991) method.

by the GH test, $\mu_{1}$ is the intercept before the shift, and $\mu_{2}$ is the change in the intercept due to the shift. The GH test reports three test statistics and each test determines the structural break. Table 3 shows GH test with structural breaks. ADF and $Z_{t}$ indicate a structural break in year 1996, respectively. However, $Z_{\alpha}$ reject the null of no cointegration with a break point. [7] show that $Z_{\alpha}$ test statistic has the lowest power of the three test statistics, possibly explaining its failure to reject the null of no cointegration.

To confirm structural breaks reported by the GH test, we run simple OLS tests including year dummies for 1996 in a regression. The results are in Table 4. In the OLS model, the estimated value of $\alpha$ is less than one, 
Table 3. Gregory-Hansen cointegration tests with a structural break.

\begin{tabular}{ccc}
\hline & Test Statistic & Break Point \\
\hline$A D F$ & $-4.97^{* *}$ & 1996 \\
$Z_{t}$ & $-5.09^{* *}$ & 1996 \\
$Z_{\alpha}$ & -22.50 & 1996 \\
\hline
\end{tabular}

${ }^{* *}$ is statistically significance at the $5 \%$ level.

Table 4. OLS regressions with structural break.

\begin{tabular}{cccc}
\hline & $\mu_{1}$ & $\mu_{2}$ & $\alpha$ \\
\hline Shift $: 1996$ & 0.114 & $0.178^{* * *}$ & $0.960^{* * *}$ \\
& $(0.369)$ & $(0.052)$ & $(0.036)$ \\
\hline
\end{tabular}

${ }^{* * *}$ is statistically significance at the $1 \%$ level.

indicating Greek debt is unsustainable. Therefore, the Greek government might have incentives to default on her debt.

\section{Conclusions}

S. Fountas and J. Wu [5] tested sustainability of Greek deficit from 1958 to 1992. Since 1992 Greece has undergone significant changes such as the election of Simitis as the prime minister in 1996, EU entry in 2000, the currency switch from drachma to euro in 2001, the 2004 Summer Olympics, financial audit in 2004, recession in 2008, and government-debt crisis in 2010. This paper tries to find if any of these events impacted Greek deficit sustainability since 1988 . Using the GH test, we reject the null hypothesis of no cointegration indicating that Greek debt is not sustainable. This test also revealed the break in 1996. The break in 1996 coincided with the election of Costas Simitis as prime minister.

The previous literature discusses the possibility that EU entry contributed to the current Greek budget problems. M. Arghyrou and D. Tsoukalas [4] discuss the contribution of EU entry to the failure of the Greek bond market. From our results, we conclude EU entry did not contribute to the Greek crisis. Instead, the election of Costas Simitis in 1996 contributed to an increase in Greek government spending. During his tenure, large public infrastructure projects such as the construction of the Athens metro and Venizelos International Airport took place in preparation for the 2004 Olympic Games. The increases in government expenditure to finance the large public projects contributed to the unsustainable Greek deficit.

\section{REFERENCES}

[1] M. Weisbrot and J. Montecino, "More Pain, No Gain for Greece: Is the Euro Worth the Costs of Pro-Cyclical Fiscal Policy and Internal Devaluation?" Center for Economic and Policy Research (CEPR), 2012.

[2] K. Margarita and M. Thomas, "EMU and the Greek Crisis: The Political-Economy Perspective," European Journal of Political Economy, Vol. 26, No. 3, 2010, pp. 568-576.

[3] M. Lynn, "Bust: Greece, the Euro and the Sovereign Debt Crisis," John Wiley \& Sons, Hoboken, 2010.

[4] M. Arghyrou and D. Tsoukalas, "The Greek Debt Crisis: Likely Causes, Mechanics and Outcomes," World Economy, Vol. 34, 2011, pp. 173-191. http://dx.doi.org/10.1111/j.1467-9701.2011.01328.x

[5] S. Fountas and J. Wu, "Are the Greek Budget Deficits Too Large?" Applied Economic Letters, Vol. 3, No. 7, 1996, pp. 487-490. http://dx.doi.org/10.1080/758540812

[6] A. W. Gregory and B. E. Hansen, "Residual-Based Tests for Cointegration in Models with Regime Shifts," Journal of Econometrics, Vol. 70, No. 1, 1996, pp. 99-126. http://dx.doi.org/10.1016/0304-4076(69)41685-7

[7] R. F. Engle and C. W. J. Granger, "Co-Integration and Error Correction: Representation, Estimation and Testing," Econometrica, Vol. 55, No. 2, 1987, pp. 251-276. http://dx.doi.org/10.2307/1913236

[8] C. Hakkio and M. Rush, "Is the Budget Deficit 'Too Large'?” Economic Inquiry, Vol. 29, No. 3, 1991, pp. 429445. http://dx.doi.org/10.1111/j.1465-7295.1991.tb00837.x

[9] EuroStat. http://epp.eurostat.ec.europa.eu/portal/page/portal/eurosta t/home/ 